\title{
ALIH FUNGSI LAHAN PERTANIAN MENJADI LAHAN NON PERTANIAN
}

\author{
Agus Ikhwanto \\ Lembaga Pemberdayaan dan Perlindungan Petani \\ Jl. Kalpataru Gg I / 87B \\ Email : agusikhwan92@gmail.com
}

\begin{abstract}
Abstrak
Kebijakan pengendalian konversi lahan pertanian pangan ke depan seyogjanya tidak hanya mengandalkan pendekatan yuridis, tetapi didukung pula dengan pendekatan ekonomi dan sosial. Setiap kebijakan konversi lahan pertanian pangan perlu diarahkan untuk mencapai 3 (tiga) sasaran yaitu, menekan intensitas faktor ekonomi dan sosial yang dapat merangsang konversi lahan sawah, mengendalikan luas lokasi dan jenis lahan yang dikonversi dalam rangka menekan potensi dampak negatif yang ditimbulkan, menetralisir dampak negatif konversi lahan sawah melalui kegiatan investasi yang melibatkan dana masyarakat terutama kalangan swata pelaku konversi lahan.
\end{abstract}

Kata Kunci: alih fungsi lahan, pangan berkelanjutan.

\section{Abstract}

The policy on controlling agricultural land conversion in the future should not only rely on a juridical approach, but also supported by economic and social approaches. Every policy on conversion of agricultural land needs to be directed at achieving 3 (three) targets, namely, suppressing the intensity of economic and social factors that can stimulate conversion of paddy fields, controlling the area and type of land converted to reduce the potential negative impacts, neutralize negative impacts conversion of paddy fields through investment activities involving community funds, especially private sector agents.

Keywords: land use change, sustainable food.

\section{PENDAHULUAN}

Indonesia merupakan negara agraris yang mempunyai sumber daya alam yang sangat kaya raya baik dari sektor pertanian, perkebunan, pertambangan dan perikanan. Dengan modal besar dan melimpah yang dimiliki negara Indonesia, seharusnya dapat mencapai kemakmuran dan kesejahteraan dalam hal pangan atas sumbangsih pertanian yang sangat besar. Kekayaan hasil pertanian akan memberikan peran penting dalam perekonomian nasional. 
Menurut Pasal 33 Ayat (3) Undang-Undang Dasar Negara Republik Indonesia Tahun 1945, "Bumi dan air dan kekayaan alam yang terkandung di dalamnya dikuasai oleh negara dan dipergunakan untuk sebesar-besar kemakmuran rakyat". Selanjutnya, dalam Undang-Undang Nomor 29 tahun 2000 tentang Perlindungan Varietas Tanaman disebutkan bahwa Negara Republik Indonesia adalah negara agraris, maka pertanian yang maju, efisien, dan tangguh mempunyai peranan yang penting dalam rangka pencapaian tujuan pembangunan nasional. Peran tersebut selanjutnya dipergunakan sebesar-besarnya untuk kemakmuran rakyat melalui: (1) pengaturan hubungan hukum antara orang dengan tanah, (2) mengatur perbuatan hukum antara orang terhadap tanah, dan (3) perencanaan persediaan peruntukan dan penggunaan tanah bagi kepentingan umum. ${ }^{1}$

Kebijakan alih fungsi lahan pertanian yang dibuat suatu Negara, termasuk Indonesia, bertujuan untuk mengatur ketersediaan lahan pertanian agar tetap stabil dan tidak menyempit, tidak mudah/cepat rusak (tetap berfungsi baik) akibat ulah/pemanfaatan para penghuninya, karena pada dasarnya peralihan lahan terjadi pada saat jaman dahulu yang bertujuan untuk mempertahankan hidup manusia. Jadi alih fungsi lahan pertanian di sini dapat menyangkut suatu tindakan untuk meningkatkan fungsi dan mengefektifkan lahan pertanian menjadi lahan sejenis dan atau merubah/mengganti fungsi lahan pertanian menjadi lahan non pertanian, bahkan ada yang langsung atau tidak langsung dapat merusak kondisi lahan tersebut, disamping dapat menjadi sumber ketegangan atau konflik antar individu atau kelompok bahkan antar negara.

Berlatar belakang sebagai negara agraris seharusnya pertanian di Indonesia perlu dikembangkan oleh pemerintah secara maksimal untuk mencapai kemakmuran dan perkembangan ekonomi masyarakat. Hal ini sejalan Indonesia adalah negara hukum pada dasarnya bertujuan untuk mensejahterakan rakyat (welfare state). Tujuan tersebut juga mengandung arti untuk segenap aspek kehidupan rakyat baik perorangan maupun kelompok masyarakat.

Dalam hal pemanfaatan lahan pertanian, Pasal 17 Undang-Undang Pokok Agraria tahun 1960 menentukan tentang batas luas maksimal dan minimal atas tanah pertanian yang boleh dimiliki perorangan atau keluarga, baik status hak milik maupun hak yang lain. Ketentuan tersebut bertujuan agar setiap orang dapat memiliki dan/atau menguasai tanah pertanian tidak melebihi ketentuan yang sudah ditentukan, sehingga dapat meningkatkan taraf hidup atau penghidupan bagi petani.

${ }^{1}$ M. Ro'i Adhi Pamungkas, Studi Normatif tentang Perizinan Alih Fungsi Lahan Pertanian Di Sukoharjo, (Surakarta: Fakultas Hukum UMS, 2017), hal. 31 
Mengacu pada keadaan masyarakat tani Indonesia, sekarang ini kurang lebih dari $60 \%$ dari para petani adalah petani tidak memiliki tanah pertanian sendiri. Sebagian mereka itu merupakan buruh tani, sebagian lagi mengerjakan tanah orang lain sebagai penyewa atau penggarap dalam hubungan perjanjian bagi hasil. Para petani yang mempunyai tanah (sawah dan/atau tanah kering) sebagian terbesar tanahnya masing-masing tanahnya kurang dari 1 hektar (rata- rata 0,6 ha tanah kering) yang hasilnya tidak cukup untuk hidup layak.

Realita yang ada masyarakat Indonesia sebagian besar menggantungkan hidupnya dengan cara bertani serta memanfaatkan lahan pertanian sebagai pekerjaan. Dengan adanya alih fungsi lahan pertanian menjadi perumahan mereka merasa dirugikan karena sulitnya irigasi serta kurangnya lahan untuk bercocok tanam karena mahalnya tanah pertanian dan menyebabkan menurunnya swasembada pangan secara drastis.

\section{METODE PENELITIAN}

Jenis penelitian ini adalah penelitian deskriptif adalah penelitian yang bertujuan untuk mendeskripsikan dan menggambarkan sesuatu hal tertentu terkait dengan alih fungsi lahan pertanian di Kota Malang. Pendekatan yang digunakan dalam penelitian ini adalah yuridis empirik, yakni melihat hukum yang didasarkan pada ketentuan peraturan perundang-undangan yang berlaku dan dikaitkan dengan melihat realita yang ada di masyarakat ${ }^{2} \mathrm{Jenis}$ data yang digunakan dalam penelitian ini terdiri atas dua macam data, yaitu data primer $^{3}$ dan data sekunder. Teknik pengumpulan data dalam penelitian ini menggunakan wawancara dan dokumentasi. Data-data yang telah terkumpul dianalisa secara deskriptif kualitatif, yaitu cara mengolah data yang ada dengan menggunakan keterangan tanpa angka-angka, sehingga diharapkan akan tersaji data yang benar-benar dapat mewakili pokok permasalahan yang dibahas ${ }^{4}$, dan akhirnya dapat ditarik suatu kesimpulan.

\section{PEMBAHASAN}

\section{Kondisi Geografis dan Geologis Kota Malang}

Sebelum menjelaskan tentang Penerapan Pasal 44 ayat (1) UndangUndang Nomor 41 Tahun 2009 tentang Perlindungan Lahan Pertanian 2002), hal.6

${ }^{2}$ Bambang Waluyo, Penelitian Hukum Dalam Praktek, (Jakarta, Sinar Grafika,

${ }^{3}$ Suratman dan Philips Dillah, Metode Penelitian Hukum, (Bandung: Penerbit Alfabeta, 2013), hal. 53.

${ }^{4}$ Rony Hantijo Soemitro, Metedologi Penelitian Dan Jurimetri Hukum, (Jakarta: Ghalia Indonesia, 1995), hal.14 
Pangan Berkelanjutan, perlu diketahui kondisi Geografis dan Geologi Kota Malang

Kota Malang memiliki luas $110.06 \mathrm{Km}^{2}$. Kota dengan jumlah penduduk sampai tahun 2010 sebesar 820.243 jiwa yang terdiri dari 404.553 jiwa penduduk laki-laki, dan penduduk perempuan sebesar 415.690 jiwa. Kepadatan penduduk kurang lebih 7.453 jiwa per kilometer persegi yang tersebar di 5 Kecamatan (Klojen: 105.907 jiwa, Blimbing: 172.333 jiwa, Kedungkandang: 174.447 jiwa, Sukun: 181.513 jiwa, dan Lowokwaru: 186.013 jiwa). Terdiri dari 57 Kelurahan, 536 unit RW dan 4.011 unit RT.

Kota Malang memiliki wilayah seluas $110,06 \mathrm{Km}^{2}$ merupakan dataran tinggi yang bervariatif. Secara geografis memiliki struktur tata ruang Kota yang sangat strategis, terletak pada lintasan transit untuk kegiatan transportasi lokal maupun regional. Kota Malang yang terletak pada ketinggian antara 440-667 meter diatas permukaan air laut, merupakan salah satu kota tujuan wisata di Jawa Timur karena potensi alam dan iklim yang dimiliki. Letaknya yang berada ditengah-tengah wilayah Kabupaten Malang secara astronomis terletak $112,06^{\circ}-112,07^{\circ}$ Bujur Timur dan $7,06^{\circ}-8,02^{\circ}$ Lintang Selatan, dengan batas wilayah sebagai berikut:

a. Sebelah Utara: Kecamatan Singosari dan Kec. Karangploso Kabupaten Malang.

b. Sebelah Timur: Kecamatan Pakis dan Kecamatan Tumpang Kabupaten Malang.

c. Sebelah Selatan: Kecamatan Tajinan dan Kecamatan Pakisaji Kabupaten Malang.

d. Sebelah Barat: Kecamatan Wagir dan Kecamatan Dau Kabupaten Malang.

Kota Malang juga berada di tengah-tengah pegunungan atau dikelilingi gunung-gunung, yaitu:

1. Gunung Arjuno di sebelah Utara.

2. Gunung Semeru di sebelah Timur.

3. Gunung Kawi dan Panderman di sebelah Barat.

4. Gunung Kelud di sebelah Selatan.

Kondisi iklim Kota Malang selama tahun 2008 tercatat rata-rata suhu udara berkisar antara $22,7^{\circ} \mathrm{C}-25,1^{\circ} \mathrm{C}$. Sedangkan suhu maksimum mencapai $32,7^{\circ} \mathrm{C}$ dan suhu minimum $18,4^{\circ} \mathrm{C}$. Rata kelembaban udara berkisar $79 \%$ 86\%. Dengan kelembaban maksimum 99\% dan minimum mencapai $40 \%$. Seperti umumnya daerah lain di Indonesia, Kota Malang mengikuti perubahan putaran 2 iklim, musim hujan, dan musim kemarau. Dari hasil pengamatan Stasiun Klimatologi Karangploso Curah hujan yang relatif tinggi terjadi pada bulan Februari, November, Desember. Sedangkan pada 
bulan Juni dan September Curah hujan relatif rendah. Kecepatan angin maksimum terjadi di bulan Mei, September, dan Juli.

\section{Badan Perencanaan Pembangunan Daerah (Bappeda) Kota Malang}

Tugas Pokok dan Fungsi Badan Perencanaan Pembangunan Daerah (Bappeda) ditetapkan melalui Peraturan Wali Kota No. 59 Tahun 2012. Adapun tugas pokoknya adalah menyusun dan melaksanakan kebijakan daerah di bidang perencanaan pembangunan daerah. Selain itu, Bappeda Kota Malang juga memiliki banyak fungsi, yaitu antara lain:

a. Meningkatkan perencanaan pembangunan yang berwawasan lingkungan.

b. Perumusan kebijakan teknis dibidang perencanaan pembangunan Daerah.

c. Penyusunan dan pelaksanaan Rencana Strategis (Renstra) dan Rencana Kerja (Renja) di bidang perencanaan pembangunan daerah.

d. Penyiapan dan penyusunan Kebijakan Umum APBD (KU-APBD).

e. Penyiapan dan Penyusunan Rancangan Rencana Pembangunan Jangka Panjang Daerah (RPJPD), Rencana Pembanguna Jangka Menengah Daerah (RPJMD), Rencana Kerja Pemerintah Daerah (RKPD).

f. Penyiapan dan penyusunan Rencana Tata Ruang Wilayah (RTRW) dan Rencana Detail Tata Ruang Kota (RDTRK).

Bidang Tata Kota merupakan sub bidang dalam tubuh Bappeda Kota Malang dimana saat penelitian ini dilangsungkan, penulis dilayani oleh sub bidang tata kota. Bidang tata kota memiliki tugas pokok yaitu untuk melaksanakan tugas pokok perencanaan tata kota. Selain memiliki tugas pokok Bidang Tata Kota Malang juga memiliki banyak fungsi, yaitu antara lain:

a. perumusan dan pelaksanaan kebijakan teknis bidang tata kota;

b. pengumpulan dan pengolahan data dalam rangka perencanaan teknis perencanaan tata kota;

c. penyusunan perencanaan dan pelaksanaan program di bidang perencanaan tata kota;

d. penyusunan rencana induk kota;

e. penyusunan Rencana Tata Ruang Wilayah (RTRW);

f. penyusunan Rencana Tata Ruang Kawasan Strategis (RTRKS);

g. penyusunan Rencana Detail Tata Ruang Kota (RDTRK) sebagai pedoman operasional pemanfaatan ruang;

h. penyusunan Rencana Tata Bangunan dan Lingkungan (RTBL);

i. penyusunan petunjuk pelaksanaan manajemen dan kelembagaan pengembangan wilayah dan kawasan;

j. penyusunan petunjuk pelaksanaan pengembangan

pembangunan perwilayahan; 
k. penyusunan rencana induk prasarana dan sarana perkotaan;

1. penyusunan kebijakan pengembangan kawasan strategis, prioritas, cepat tumbuh dan andalan kota.

Isu hukum yang pertama diteliti atau dianalisis dalam penelitian ini terkait dengan ketentuan pasal 44 ayat (1) Undang-Undang Nomor 41 Tahun 2009 tentang Perlindungan Lahan Pertanian Pangan Berkelanjutan.

\section{Badan Perencanaan Pembangunan Daerah (Bappeda) Kota Malang}

Tugas Pokok dan Fungsi Badan Perencanaan Pembangunan Daerah (Bappeda) ditetapkan melalui Peraturan Wali Kota No. 59 Tahun 2012. Adapun tugas pokoknya adalah menyusun dan melaksanakan kebijakan daerah di bidang perencanaan pembangunan daerah. Selain itu, Bappeda Kota Malang juga memiliki banyak fungsi, yaitu antara lain:

g. Meningkatkan perencanaan pembangunan yang berwawasan lingkungan.

h. Perumusan kebijakan teknis dibidang perencanaan pembangunan Daerah.

i. Penyusunan dan pelaksanaan Rencana Strategis (Renstra) dan Rencana Kerja (Renja) di bidang perencanaan pembangunan daerah.

j. Penyiapan dan penyusunan Kebijakan Umum APBD (KU-APBD).

k. Penyiapan dan Penyusunan Rancangan Rencana Pembangunan Jangka Panjang Daerah (RPJPD), Rencana Pembanguna Jangka Menengah Daerah (RPJMD), Rencana Kerja Pemerintah Daerah (RKPD).

1. Penyiapan dan penyusunan Rencana Tata Ruang Wilayah (RTRW) dan Rencana Detail Tata Ruang Kota (RDTRK).

Bidang Tata Kota merupakan sub bidang dalam tubuh Bappeda Kota Malang dimana saat penelitian ini dilangsungkan, penulis dilayani oleh sub bidang tata kota. Bidang tata kota memiliki tugas pokok yaitu untuk melaksanakan tugas pokok perencanaan tata kota. Selain memiliki tugas pokok Bidang Tata Kota Malang juga memiliki banyak fungsi, yaitu antara lain:

m. perumusan dan pelaksanaan kebijakan teknis bidang tata kota;

n. pengumpulan dan pengolahan data dalam rangka perencanaan teknis perencanaan tata kota;

o. penyusunan perencanaan dan pelaksanaan program di bidang perencanaan tata kota;

p. penyusunan rencana induk kota;

q. penyusunan Rencana Tata Ruang Wilayah (RTRW);

r. penyusunan Rencana Tata Ruang Kawasan Strategis (RTRKS);

s. penyusunan Rencana Detail Tata Ruang Kota (RDTRK) sebagai pedoman operasional pemanfaatan ruang;

t. penyusunan Rencana Tata Bangunan dan Lingkungan (RTBL); 
u. penyusunan petunjuk pelaksanaan manajemen dan kelembagaan pengembangan wilayah dan kawasan;

v. penyusunan petunjuk pelaksanaan pengembangan pembangunan perwilayahan;

w. penyusunan rencana induk prasarana dan sarana perkotaan;

$\mathrm{x}$. penyusunan kebijakan pengembangan kawasan strategis, prioritas, cepat tumbuh dan andalan kota.

Isu hukum yang pertama diteliti atau dianalisis dalam penelitian ini terkait dengan ketentuan pasal 44 ayat (1) Undang-Undang Nomor 41 Tahun 2009 tentang Perlindungan Lahan Pertanian Pangan Berkelanjutan.

\section{Perlindungan Lahan Pertanian Pangan Berkelanjutan}

Perlindungan dalam bahasan ini terfokus pada perlindungan hukum.Terkait dengan teori perlindungan hukum, ada beberapa ahli yang menjelaskan bahasan ini, antara lain yaitu Fitzgerald, Satjipto Raharjo, Phillipus M Hanjon dan ahli lainnya. Fitzgerald mengutip istilah teori perlindungan hukum dari Salmond bahwa hukum bertujuan mengintegrasikan dan mengkoordinasikan berbagai kepentingan dalam masyrakat karena dalam suatu lalulintas kepentingan, perlindungan terhadap kepentingan tertentu dapat dilakukan dengan cara membatasi berbagai kepentingan di lain pihak. Kepentingan hukum adalah mengurusi hak dan kepentingan manusia, sehingga hukum memiliki otoritas tertinggi untuk menentukan kepentingan manusia yang perlu diatur dan dilindungi. Perlindungan hukum harus melihat tahapan yakni perlindungan hukum lahir dari suatu ketentuan hukum dan segala peraturan hukum yang diberikan oleh masyarakat yang pada dasarnya merupkan kesepakatan masyarakat tersebut untuk mengatur hubungan perilaku antara anggota-anggota masyarakat dan antara perseorangan dengan pemerintah yang dianggap mewakili kepentingan masyarakat. ${ }^{5}$

Menurut Satjipto Rahardjo, perlindungan hukum adalah memberikan pengayoman terhadap hak asasi manusia (HAM) yang dirugikan orang lain dan perlindungan itu diberikan kepada masyarakat agar dapat menikmati semua hak-hak yang diberikan oleh hukum. ${ }^{6}$ Phillipus M. Hadjon bahwa perlindungan hukum bagi rakyat sebagai tindakan pemerintah yang bersifat preventif dan resprensif. Perlindungan uukum yang preventif bertujuan untuk mencegah terjadinya sengketa, yang mengarahkan tindakan pemerintah bersikap hati-hati dalam pengambilan keputusan berdasarkandiskresi dan perlindungan yang resprensif bertujuan untuk mencegah terjadinya sengketa, termasuk penanganannya di lembaga

${ }^{55}$ Satjipto Raharjo,Ilmu Hukum (Bandung: PT.Citra Aditya Bakti, 2000), hal.53

${ }^{6}$ Ibid, hal. 69. 
peradilan.. ${ }^{7}$ Menurut Lili Rasjidi dan I.B Wysa Putra bahwa hukum dapat didifungsikan untuk menghujudkan perlindungan yang sifatnya tidak sekedar adaptif dan fleksibel, melaikan juga predektif dan antipatif. ${ }^{8}$

Perlindungan hukum adalah segala upaya pemenuhan hak dan pemberian bantuan untuk memberikan rasa aman kepada saksi dan/atau korban, perlindungan hukum korban kejahatan sebagai bagian dari perlindungan masyarakat, dapat diwujudkan dalam berbagai bentuk, seperti melalui pemberian restitusi, kompensasi, pelayanan medis, dan bantuan hukum. $1^{9}$

Sejak manusia pertama kali menempati bumi, lahan sudah menjadi salah satu unsur utama dalam menunjang kelangsungan kehidupan. Konkritnya, lahan difungsikan sebagai tempat manusia beraktivitas untuk mempertahankan eksistensi. Aktivitas yang pertama kali dilakukan adalah pemanfaatan lahan untuk bercocok tanam (pertanian). Kegiatan pertanian merupakan salah satu aktifitas paling mendasar bagi manusia, karena semua orang perlu makan setiap hari. Pengembangan usaha agribisnis menjadi pilihan sangat strategis dan penting sejalan dengan upaya pemerintah dalam mengembangkan sumber-sumber pertumbuhan ekonomi baru diluar minyak dan gas.

Dalam sejarah Indonesia pernah mampu mencapai swasembada pangan pada tahun 1984 melalui gerakan "revolusi hijau" yaitu gerakan untuk meningkatkan produksi pangan melalui usaha pengembangan teknologi pertanian. keberhasilan gerakan "revolusi hijau" merupakan bukti upaya pemerintah dalam meningkatkan kesejahteraan petani. Seiring pertumbuhan populasi dan perkembangan peradaban manusia, penguasaan dan penggunaan lahan mulai terusik. Keterusikan ini akhirnya menimbulkan kompleksitas permasalahan akibat pertambahan jumlah penduduk, penemuan dan pemanfaatan teknologi, serta dinamika pembangunan. Lahan yang semula berfungsi sebagai media bercocok tanam (pertanian), berangsur-angsur berubah menjadi multifungsi pemanfaatan. ${ }^{10}$

Pembukaan Undang-Undang Dasar Negara Kesatuan Republik Indonesia Tahun 1945 menyebutkan bahwa tujuan bernegara adalah

\section{${ }^{7}$ Ibid, hal. 54.}

${ }^{8}$ Lili Rasjidi dan I.B Wysa Putra, Hukum Sebagai Suatu Sistem, (Bandung :Remaja Rosdakarya, 1993), hal. 118.

${ }^{9}$ Soerjono Soekanto, Pengantar Penelitian Hukum, (Jakarta: UI Press, 1984), hal. 133.

${ }^{10}$ Musleh Herry dan Imam Sukadi, "Efektifitas Perlindungan Hukum Terhadap Lahan Pertanian Produktif Di Kota Malang", Lembaga Penelitian dan Pengabdian Masyaratakat Universitas Islam Negeri Maulana Malik Ibrahim Malang. 2015, hal. 87. 
"melindungi segenap bangsa Indonesia dan seluruh tumpah darah Indonesia dan untuk memajukan kesejahteraan umum, mencerdaskan kehidupan bangsa dan ikut melaksanakan ketertiban dunia yang berdasarkan kemerdekaan, perdamaian abadi, dan keadilan sosial". Oleh karena itu, perlindungan segenap bangsa dan peningkatan kesejahteraan umum adalah tanggung jawab penting bernegara. Apalagi menyangkut tentang perlindungan fungsi tanah oleh negara pada lahan pertanian terhadap alih fungsi lahan atau yang dikenal dengan konversi lahan.

Indonesia merupakan negara agraris yang diartikan tanah dan dihubungkan dengan usaha pertanian. Di dalam kehidupan kita, tanah memiliki peranan yang sangat penting dalam kehidupan pembangunan bangsa, karena didalam konstitusi Undang-Undang Dasar Negara Kesatuan Republik Indonesia Tahun 1945 yang dituangkan dalam Pasal 33 ayat (3) menyebutkan bahwa: "Bumi dan air dan kekayaan alam yang terkandung didalamnya dikuasai oleh Negara dan digunakan untuk sebesar-besar kemakmuran rakyat".

Untuk itu perlu adanya perangkat peraturan yang komprehensif terkait perlindungan lahan dan upaya pemberian insentif kepada petani maka diharapkan tanah tersedia bagi petani bukan hanya untuk menjamin ketersediaan produksi pangan, namun lebih jauh menjamin akses petani atas lahan untuk meningkatkan kesejahteraan petani. Indonesia dikenal sebagai negara lumbung padi yang artinya menghasilkan padi yang sangat banyak, baik untuk negara sendiri maupun diekspor ke negara lain. Tetapi saat sekarang ini kita merasakan jumlah rumah tangga dengan usaha pertanian terus menurun akibat beberapa hal diantaranya alih profesi dan semakin sempitnya lahan pertanian karena alih fungsi lahan untuk pembangunan infrastruktur, pembangunan pabrik dan perumahan. ${ }^{11}$

Sektor pertanian dihadapkan pada berbagai masalah dan tantangan, Ditinjau dari aspek pertanahan, permasalahan utama sektor pertanian antara lain adalah semakin terbatasnya sumberdaya lahan yang cocok untuk dikembangkan bagi kegiatan pertanian, sempitnya rata'-rata penguasaan lahan pertanian perkapita penduduk Indonesia (900 m2/kapita). serta makin dominannya petani berlahan sempit. Disisi lain sulitnya upaya pengendalian alih fungsi lahan pertanian, khususnya lahan sawah beririgasi teknis ke berbagai penggunaan serta masalah-masalah yang menyangkut struktur penguasaan lahan pertanian merupakan masalah yang perlu ditangani secara-menyeluruh. Uraian pada bagian ini akan memaparkan kondisi saat ini dari penguasaan dan pengusahaan lahan, serta berbagai permasalahan yang terkait dengan kedua hal tersebut.

${ }^{11}$ Musthafa Ika, "Perlindungan Hukum Terhadap Lahan Pertanian Pangan Dari Konversi Lahan di Kota Padang”. Thesis, Universitas Andalas, Padang, 2017, hal. 54. 
Permasalahan pertama, tingginya tingkat konversi lahan sawah ke penggunaan lain. Berbagai prediksi pesimis memperkirakan sekitar tahun 2020 China akan menjadi importir utama beras dunia. Hal ini tidak saja akan mendorong harga beras membumbung tinggi, namun juga sulit untuk mendapatkannya. Jadi, dalam jangka panjang sangat riskan bila kebutuhan pangan tergantung kepada impor. Semakin meningkatnya konversi lahan sawah ke non pertanian; maka kondisi ini akan sangat mempengaruhi ketahanan pangan di Indonesia untuk masa yang akan datang. Masalah keterbatasan ketersediaan informasi lahan yang konsisten Informasi mengenai informasi ketersediaan lahan, penggunaan lahan serta konversi lahan secara teknis, ternyata didefinisikan dan diukur dengan cara yang berbeda. Berbagai pihak yang terkait dan berkepentingan dengan masalah ketersediaan lahan dan konversi lahan seringkali beranjak dengan dasar standar data yang tidak sama sehingga seringkali sangat sulit untuk saling memperbandingkan satu sarna lainnya akibatnya banyak menimbulkan berbagai interpretasi yang beragam.

Permasalahan lingkungan tidak pernah terlepas dari tindakan para agen atau manusia yang melakukan pembangunan tanpa memperhatikan tata ruang terbuka hijau yang sebenarnya sangat berpengaruh terhadap keseimbangan lingkungan. Padahal sawah itu sangat membantu produksi pangan yang sangat dibutuhkan oleh para manusia.

Angka alih fungsi tanah pertanian ke non pertanian dari tahun ke tahun semakin meningkat tajam. Sensus pertanian 2003 menyebutkan selama periode 2000-2002 total luas tanah sawah di Indonesia yang dikonversi ke penggunaan lain mencapai 563.000 hektar atau rata-rata 187,7 ribu hektar per tahun. Dengan luas sawah 7,75 juta hektar pada tahun 2002, pengurangan luas sawah akibat konversi lahan mencapai 7,27\% selama 3 tahun atau rata-rata $2,42 \%$ per tahun. ${ }^{12}$

Di Kota Malang, Jawa Timur yang luas wilayah sebesar 110,06 km² dari tahun ke tahun terus menyusut karena beralihfungsi lahan pertanian menjadi kawasan perumahan (permukiman) maupun sebagai kawasan yang digunakan untuk perekonomian.

Kepala Dinas Pertanian Kota Malang, Ninik Suryantini, menjelaskan bahwa pada tahun 2007 luas lahan pertanian di daerah itu mencapai 1.550 hektar, tahun 2009 menyusut menjadi 1.400 hektar dan tahun ini tinggal 1.300 hektare. Di Kecamatan Klojen yang merupakan pusat kota sudah tidak ada lagi persawahan yang diakibatkan oleh pembangunan sarana umum yang terus bertambah. Sedangkan di daerah Lowokwaru memiliki lahan pertanian dengan rincian jenis sawah yang dominan adalah sawah

\footnotetext{
${ }^{12}$ https://www.bps.go.id/publication/2005/05/15/a8ef1846eee2161f35895daa/statist ik-indonesia-2004.html, akses 15 November 2018.
} 
irigasi tehnis seluas $1.523,343$ ha dan sederhana non tehnis seluas $6.918,156$ ha. Sawah dapat difungsikan sebagai lahan pertanian dengan hasil utama padi. Lokasi persawahan terdapat di wilayah Merjosari, Tunggulwulung, Tasikmadu.

\section{Mekanisme atau Prosedur Alih Fungsi Lahan Pertanian di Kota Malang}

Mekanisme atau Prosedur pengajuan pengalih fungsian lahan pertanian ke non pertanian di Kota Malang pada prinsipnya harus mendapatkan ijin dari instansi terkait. Dalam hal melaksanakan konversi lahan tersebut, sebelumnya pemilik lahan memang harus memperoleh Ijin Perubahan Penggunaan Tanah (IPPT), Ijin perubahan penggunaan tanah dari tanah pertanian ke non pertanian diajukan kepada Badan Pertanahan Nasional Republik Indonesia (BPNRI) berwenang mengeluarkan pertimbangan teknis pertanahan dalam rangka penerbitan IPPT tersebut. Namun kondisi yang berlaku di tiap-tiap daerah berbeda-beda, ada IPPT yang dikeluarkan oleh Bupati/Walikota, sebagaimana diatur dalam Peraturan Daerah, ada pula IPPT yang dikeluarkan oleh Kepala Kantor Pertanahan yang berupa Risalah Pertimbangan Teknis Pertanahan.

Seperti halnya yang berlaku di Kota Malang apabila ada pengajuan konversi lahan dari pertanian ke non pertanian atau dengan istilah proses pendaratan, maka apabila lahan pertaninan tersebut berada di daerah perkotaaan dan bukan merupakan lahan basah (jalur kuning) maka proses konversi lahan dapat langsung didaftarkan. Mekanisme pengalihfungsian lahan terlebih dahulu dengan mendapatkan Surat Rekomendasi dari Kantor Bapeda, rekomenassi dari Dinas Perkimatru dengan dikeluarkannya site plan atau gambar rencangan bangunan yang ditandatangani Kepala Dinas tersebut. Selanjutnya harus mendapatkan Rekomendasi dari Dinas Pertanian dan Ketahanan Pangan, Surat Perubahan Teknis Pertanahan dari BPN dan terakhir Surat Keputusan dari Dinas Perijinan Terpadu yang kemudian Surat Keputusan (SK) tersebut didaftarkan kembali untuk dicatatkan di Kantor Badan Pertanahan Nasional (BPN) Kota Malang.

Namun, apabila lahan tersebut merupkan lahan basah atau berada di jalur hijau maka harus mendapatkan ijin peruntukan lahan terlebih dahulu dari Badan Perencanaan Pembangunan Daerah (BAPPEDA) Kota Malang. Untuk mendapatkan Surat Ijin Peruntukan Lahan dari BAPPEDA pun tidaklah mudah, karena harus membawa dan menunjukkan kelengkapan administratif serta bukti otentik keadaan lahan yang akan dikonversi tersebut.

Adapun syarat untuk Izin Perubahan Penggunaan Tanah (IPPT) yang harus diajukan adalah sebagai berikut: 
1. Fotokopi KTP pemohon;

2. Surat kuasa (bisa dikuasakan) beserta KTP dan C1 (Kartu Keluarga);

3. Akta pendirian badan hukum;

4. Pengesahan badan hokum;

5. Fotokopi alas hak, bisa berupa sertipikat, leter $\mathrm{C}$ dan sebagainya;

6. Surat keterangan NPWP;

7. SPPT/PBB dan pelunasannya;

8. Pernyataan kesanggupan akan memberikan ganti kerugian yang berhak atas tanah;

9. Sket gambar atau denah lokasi tanah yang dimohon;

10. Sket rencana penggunaan tanah;

11. Uraian rencana proyek;

12. Kesesuaian aspek tata ruang (ATR) dari Dinas PU;

13. Surat keanggotaan REI (untuk pengembang perumahan);

14. Surat pernyataan kerelaan dari pemilik tanah beserta KTP atau akta perikatan jual beli dari calon tanah yang akan dibeli;

15. Sosialisasi kepada masyarakat sekitar atas rencana kegiatan;

16. Surat keterangan tanah-tanah yang sudah dimiliki oleh perusahaan; dan

17. Dokumen penunjang lainnya yang terkait dengan kegiatan tersebut. ${ }^{13}$ Berdasarkan deskripsi tersebut, maka dapat dipahami mengenai Faktor-faktor yang menyebabkan terjadinya alih fungsi lahan pertanian menjadi lahan non pertanian yang secara garis besar bisa dikategorikan menjadi tiga, yaitu: (a) Faktor eksternal, yang disebabkan oleh adanya dinamika pertumbuhan perkotaan, demografi maupun ekonomi; (b) Faktor internal, yang disebabkan oleh kondisi sosial-ekonomi rumah tangga pemilik lahan pertanian dan pengguna lahan pertanian; dan (c) Faktor kebijakan pemerintah, yaitu regulasi yang dikeluarkan oleh pemerintah pusat maupun daerah yang berkaitan dengan alih fungsi lahan pertanian yang tidak efektif dalam pelaksanaksaannya, termasuk di Kota Malang. Kelemahan regulasi terutama terkait dengan masalah kekuatan hukum, sanksi pelanggaran, dan akurasi objek lahan yang dilarang dikonversi. Berdasarkan penelitian, faktor-faktor yang menyebabkan alih fungsi lahan pertanian di Kota Malang terutama karena pertumbuhan sektor ekonomi dan industri yang membutuhkan banyak lahan untuk melakukan kegiatannya.

Dari aspek mekanisme atau prosedur pengajuan pengalihfungsian (konversi) lahan pertanian ke non pertanian di Kota Malang pada prinsipnya harus mendapatkan ijin dari instansi terkait. Dalam hal melaksanakan

${ }^{13}$ http://jogja.tribunnews.com/2016/05/18/bagaimana-bangun-perumahan-di-lahanpertanian, 15 November 2018 
konversi lahan, pemilik lahan harus memperoleh Ijin Perubahan Penggunaan Tanah (IPPT). IPPT dari tanah pertanian ke non pertanian diajukan kepada Badan Pertanahan Nasional Republik Indonesia (BPNRI) berwenang mengeluarkan pertimbangan teknis pertanahan dalam rangka penerbitan IPPT tersebut.

\section{KESIMPULAN}

Laju pertumbuhan penduduk dan pembangunan yang pesat memerlukan lahan-lahan baru sehingga menimbulkan kompetisi penggunaan lahan dan alih fungsi lahan pertanian pangan menjadi lahan non pertanian yang dapat mengancam ketahanan dan kemandirian pangan. Pemerintah Daerah wajib melakukan perlindungan Lahan Pertanian Pangan Berkelanjutan dalam rangka terjaminnya hak atas pangan bagi masyarakat. Guna melindungi lahan pertanian pangan dari alih fungsi lahan sesuai amanat ketentuan Undang-Undang Nomor 41 Tahun 2009 tentang Perlindungan Lahan Pertanian Pangan Berkelanjutan, mestinya setiap daerah telah memiliki Peraturan Daerah tentang Rencana Tata Ruang Wilayah (RTRW) yang di dalamnya juga mengatur penetapan lahan pertanian pangan yang harus mendapatkan perlindungan dengan cara melarang untuk dilakukan alih fungsi menjadi lahan non pertanian, kecuali untuk kepentingan umum atau karena bencana alam.

\section{DAFTAR PUSTAKA}

\section{Buku}

Bambang Waluyo, 2002, Penelitian Hukum Dalam Praktek, Jakarta, Sinar Grafika.

Rony Hantijo Soemitro, 1995, Metedologi Penelitian Dan Jurimetri Hukum, Jakarta: Ghalia Indonesia.

Satjipto Raharjo, 2000, Ilmu Hukum, Bandung: PT.Citra Aditya Bakti.

Soerjono Soekanto, 1984, Pengantar Penelitian Hukum, Jakarta: UI Press.

Suratman dan Philips Dillah, 2013, Metode Penelitian Hukum, Bandung: Penerbit Alfabeta, 2013.

Lili Rasjidi dan I.B Wysa Putra, 1993, Hukum Sebagai Suatu Sistem, Bandung :Remaja Rosdakarya.

\section{Laporan Penelitian dan Tesis}

M. Ro'i Adhi Pamungkas, 2017, "Studi Normatif tentang Perizinan Alih Fungsi Lahan Pertanian Di Sukoharjo", Surabarta: Fakultas Hukum UMS. 
Musleh Herry dan Imam Sukadi, 2015, "Efektifitas Perlindungan Hukum Terhadap Lahan Pertanian Produktif Di Kota Malang”, Lembaga Penelitian dan Pengabdian Masyaratakat Universitas Islam Negeri Maulana Malik Ibrahim Malang.

Musthafa Ika, 2017, "Perlindungan Hukum Terhadap Lahan Pertanian Pangan Dari Konversi Lahan di Kota Padang". Tesis, Andalas, Padang.

\section{Peraturan Perundang-undangan}

Peraturan Walikota Malang Nomor 59 Tahun 2012 tentang Uraian Tugas Pokok, Fungsi dan Tata Kerja Badan Perencanaan Pembangunan Daerah.

Peraturan Walikota Malang Nomor 59 Tahun 2012 tentang Uraian Tugas Pokok, Fungsi dan Tata Kerja Badan Perencanaan Pembangunan Daerah.

Undang-Undang No. 56 PRp 1960 Tentang Penetapan Luas Tanah Pertanian.

Undang-Undang Pokok Agraria Undang-Undang No. 5/ 1960.

\section{Internet}

https://www.bps.go.id/publication/2005/05/15/a8ef1846eee2161f35895daa/s tatistik-indonesia-2004.html, akses 15 November 2018.

http://jogja.tribunnews.com/2016/05/18/bagaimana-bangun-perumahan-dilahan-pertanian, 15 November 2018 